\title{
Dilemmas for advocacy organisations in Myanmar's changing political landscape
}

Edition 1, 2020

Dr Tamas Wells, Dr Vanessa Lamb

DOI: 10.37839/MAR2652-550X1.2

Tamas Wells, Research Fellow, School of Social and Political Sciences, University of Melbourne (lead author); and

Vanessa Lamb, Senior Lecturer, School of Geography, University of Melbourne.

Early last year, U Win Myo Thu-the chairman of a local environmental advocacy organization ECODEV-took the microphone at a public consultation meeting over a major new planning project, known as New Yangon City.

The \$US1.5-billion project is being led by the New Yangon Development Company. The company is described as "100\% owned" by the Yangon Regional Government but the project itself is a public-private partnership. Company's CEO Serge Pun had made a presentation to the large town hall audience about progress in project planning and a new agreement made with China Communications Construction Company.

In response, U Win Myo Thu questioned the project plans, asking Serge Pun about the dangers associated with Chinese investment and the environmental and economic risks of the project. U Win Myo Thu said that the project sounded 'too good to be true' and wondered if there were 'hidden agendas' amongst the project's investors. 
This exchange was significant because the New Yangon City project had, to that point, received limited public criticism or attention, despite involving many highlycontroversial dimensions. This contrasts with planning processes for past highprofile development projects such as the Myitsone dam or the Dawei and Thilawa Special Economic Zone projects. These projects had been the target of vigorous public campaigning by advocacy groups such as Dawei Development Association during the military-backed Thein Sein government from 2011 to 2015.

Under the government of Daw Aung San Suu Kyi's National League for Democracy there are political realignments which have reshaped advocacy activity. Decisionmaking in this new political landscape has posed new difficulties for advocacy organisations in their efforts to effectively challenge large planning projects. The new political landscape requires new approaches to those used under the militarybacked Thein Sein government of the past.

In this case, closer attention to the New Yangon City project planning revealed processes of depoliticization via technical and managerial means within ostensibly democratic and inclusive planning processes. Processes of depoliticization present dilemmas for advocacy organizations, as they are forced to either engage in planning processes in a circumscribed and technical manner, or as U Win Myo Thu experienced, risk being marginalized through more direct confrontation with government and private sector actors.

\section{The controversies of New Yangon City}

The idea of expanding Yangon city to the west over the Yangon River has been considered for more than a decade, but it is only since 2018 that tangible progress had been made. Decades of urban expansion in Yangon has largely concentrated on the region north of the city, while 80 square kilometres of farmland lay just across the Yangon River from the downtown area.

After the historic victory of Suu Kyi's NLD party in the 2015 elections, the project 
was considered by the NLD regional government; and strongly supported by U Phyo Min Thein - an NLD politician, Yangon Chief Minister and former political prisoner.

In early 2018, U Phyo Min Thein's Yangon regional government incorporated the New Yangon Development Company, responsible for the implementation of the project.

According to NYDC, the plan is to develop 'an urban industrial district that will initiate creation of 2 million jobs'. Serge Pun, who has been prominent in Myanmar's private sector since the authoritarian period, was appointed CEO of NYDC. He has interests in real estate, healthcare and finance and - with a net worth of more than $\$ 800$ million - was previously ranked number 35 in Singapore's Richest 50 in Forbes magazine. Despite his previous investments in Myanmar during the authoritarian period, he has avoided portrayal as a 'crony' and enjoys cooperation with the NLD. Serge Pun took a lead role in the public consultations around the New Yangon City project planning.

As U Win Myo Thu's comments raised in the 2019 public consultation meeting, Chinese investment is one of the most controversial dimensions of the project.

China Communications Construction Company (CCCC), which is a key contactor in the Belt and Road Initiative, was sanctioned (debarred) by the World Bank from 2009-2017 for allegations of fraud and corruption in a highway project in the Philippines. In 2018, CCCC was also the target of citizen protests in Sri Lanka for its key role in the Port City Colombo project and criticism related to environmental damage from sand dredging north of Colombo. Overall CCCC is involved in more than 700 projects across Asia, Africa, and Latin America, and the company has been embroiled in a string of other controversies from Malaysia to Kenya and Bangladesh.

Beyond these concerns about Chinese investment, the project has other controversial dimensions. One of the reasons the New Yangon City expansion has not been developed earlier is that the proposed site west of the Yangon River is highly flood prone - only 3-5 metres above sea level, is near the confluence of the 
Yangon and Bago rivers and is in an area of high rainfall.

U Win Myo Thu and other critics have also questioned the economic viability of the project - given the large initial investment required and its long term and uncertain returns - and the opportunity cost of the project. Their argument is that new capital should be spent on existing deficiencies in Yangon's water, housing, electricity, and sanitation infrastructure rather than diverting money to a new high-cost suburb.

The New Yangon City project is a large-scale project with seemingly high risks associated with environmental, geopolitical, and economic outcomes. Why then is this project not a target of high-profile campaigning by Myanmar advocacy organisations, as other similar projects have been?

\section{Depoliticisation, through delegation, individualisation and restructuring}

In the last decade, urban studies have been invigorated by the examination of how decision-making has become dominated by managerial and consensual forms of democracy, a process described as depoliticisation.

Growing out of a perceived loss of grand ideological debate since the fall of the Berlin Wall, theorists such as political theorists Erik Swyngedouw, Jacques Ranciere, and others argue that democracy has two faces: Decision-making processes can be inclusive and participatory, and yet eschew contest by reducing what are essentially social and political problems to the technical realm. Challenges can be managed by experts who provide individuals with specific choices which foreclose broader questioning.

We argue that the two faces of democracy - the inclusive, participatory face and the face that denies contest - are held together through particular processes of depoliticisation. Of relevance for the case of New Yangon City are processes of delegation, individualisation, and restructuring. 
First, there is a delegation of problem solving away from the political realm of parliaments and politicians, to technocrats and consultants. Decisions are, as Burnham argues, 'at one remove' from political processes. Second, when there are participatory processes, they are often structured to address the particular rather than the universal. There is an individualisation of challenges and responses rather than opportunities for collective action. Finally, the citizen-state relationship - and the role of civil society - is restructured through diffuse forms of governance beyond the state. With proliferation of supranational and subnational governance bodies and private and public sector bodies - which also often include 'civil society representatives' - governance becomes dispersed and pathways of responsibility for policy decisions are less certain.

These processes of delegation, individualisation, and restructuring provide both opportunities and constraints for advocacy organizations. On one hand, the delegation and restructuring provide opportunities for civil society networks to have direct involvement in decision making through provision of technical support or through representation in governance bodies. On the other hand, these processes of depoliticisation circumscribe the potential communications and actions of advocacy groups - leaving them with the dilemma of either engaging in a purely technocratic manner or agitating beyond the narrowly defined choices and risking being dismissed as irrelevant or extreme.

\section{Delegation, individualisation and restructuring in relation to the New Yangon City project}

Since the 2015 elections, Myanmar's political alignments have shifted. After decades of military and then quasi-military rule, the NLD party - which comprised many political prisoners, Suu Kyi included - enjoyed a landslide victory. 
Earlier in the 2000s, campaigning by advocacy organizations within Myanmar was necessarily muted and disguised behind sophisticated messaging designed to avoid hard crackdowns by the government. Yet after 2011, advocacy groups - from grassroots labour organisations through to national level and donor-funded initiatives - began to take a more open and public role in policy advocacy. Whilst differing along lines of ideology, ethnicity, or religion, many of these advocacy groups were aligned with the NLD-led opposition movement before 2015.

Yet after the 2015 election victory, the dynamics of advocacy necessarily shifted. Military or ex-military elites were no longer the only target of advocacy. The NLD, as long-time allies of advocacy organisations, was thrust into decision-making positions, including in relation to large development projects such as New Yangon City. In contrast to advocacy campaigns against the Myitsone dam or the Dawei development project, which were military backed, the New Yangon City project is publicly supported by NLD and Yangon Chief Minister U Phyo Min Thein. At one level, therefore, the limited recent critique of the New Yangon City project can be explained by shifting political alignments and caution by activists - some of whom have advisory roles to the NLD - in relation to overt criticism of U Phyo Min Thein.

Further, since 2015, the NLD has also shown that it not afraid to punish its critics. Press freedom has diminished in Myanmar since 2015, and there have been several high-profile cases of arrests of journalists. The legacy of authoritarian control in Myanmar continues, at least to some degree, and advocacy groups are aware that there are lines which are not to be crossed.

However, these explanations for the lack of public debate and civil society advocacy around the New Yangon City project are insufficient. We are suggest instead that coupled with these constraints of political realignments and lingering civil society suppression are new dynamics of depoliticisation through delegation, individualization, and restructuring.

Since the incorporation of NYDC in 2018, the company has initiated an array of 
technical analyses, delegating some key project decision making to consultancies. McKinsey Consulting was engaged - and funded by the United Kingdom's Department for International Development - to write a socioeconomic Master Plan for the project. The Plan envisages that the NYDC will be a 'a model organisation adopting and upholding world-class governance mechanisms'. The Australian firm Environmental Resources Management conducted an environmental impact assessment in early 2019, and the Dutch consultancy Royal Haskoning DHV was engaged in 2019 to study flood risk at the site.

While these consultancies progressed, decisions about the New Yangon City project have not been brought before the Yangon regional parliament. NYDC and the NLD have effectively delegated decision making around project implementation to technical experts while they, and the public, remain 'at one remove' from those decisions.

This leaves limited opportunities for substantive engagement by advocacy organisations. Advocacy organizations are forced to engage on a technical level interacting with international consultancy firms with considerable prestige while having vastly less access to technical information. At the same time, advocacy groups have been denied the opportunity to contribute to political debate through parliament. The delegation of project planning to external technical consultancies and away from political institutions and politicians - serves to narrow the scope for advocacy organization influence.

Along with delegation to the technical arena, the planning process also separated stakeholders and individualized choice. NYDC conducted a series of consultations about the project, and these demonstrated the two faces of democracy described by Swyngedouw: participatory and inclusive and yet restricted opportunities for debate.

Importantly, consultation meetings were sedimented, involving three different forums for particular sets of stakeholders. From June 2018, there were several town hall style meetings conducted held in central Yangon. These meetings in central 
Yangon attracted private sector, civil society, and government elites. Then, at the township level, NYDC consulted with local level government bureaucrats. Finally, at the village level, NYDC held consultation meetings with community members to discuss the project and plans for land compensation. On one hand, these consultation meetings were inclusive and provided a forum for open questioning by public and elites. However, the sedimentation of consultation into separate groups served to limit the potential for criticism and debate. This led to an individualization of participation and curtailed collective networking and decision making that could cut across local and elite divides. Processes of consultation meant that project challenges could be addressed only at the level of the particular (for example, issues related to land compensation rates) rather than the universal (for example, whether or not the project should go ahead).

Finally, the New Yangon City project planning was depoliticized through a restructuring of citizen-state relations. The New Yangon City project was initiated by Chief Minister U Phyo Min Thein (without parliamentary approval) but then responsibility for implementation of the project was handed to the state-owned NYDC led by Serge Pun. The implementation, however, would also be managed by Chinese state-owned enterprise CCCC. Further complicating the governance structure is the ways in which the proposed New Yangon City site lies almost entirely outside the authority of Yangon's municipal government, the Yangon City Development Committee (YCDC) which raises its own taxes and revenue and provides basic services in the city. It is unclear therefore what municipal governance structure would be in place for New Yangon City.

Amidst this dispersed arrangement of governance actors - involving regional government, municipal government, Myanmar state-owned enterprise, and Chinese state-owned enterprise - it is challenging for advocacy groups to target critiques around the project planning. Responsibility for the project is dispersed and governance processes are complex and opaque.

For advocacy organisations in Myanmar, the authoritarian era presented a context of 
repression. However, in some ways, the structure of citizen-state relationships was clear with policy decision making highly centralised. Since 2015, and with a proliferation of supranational and subnational bodies, foreign investment, and civil society involvement, policy decision-making processes are at once both more participatory and more opaque. These dynamics have also been present in the implementation of other megaprojects in Myanmar.

\section{Conclusion}

With new forms of democratic governance since the transition in Myanmar - and with the increase in foreign investment - there are new kinds of opportunities and constraints for advocacy groups.

Processes of delegation, individualization, and restructuring serve, on the one hand, to open new opportunities for advocacy organisations to influence decision making: public consultations and technical processes allow new avenues for advocacy groups to engage with projects such as New Yangon City.

However, on the other hand, these processes of depoliticization also constrain advocacy groups if they wish to fundamentally challenge the rationale of projects or mobilise collective action against project decision making.

While Myanmar's advocacy groups still face some legacies of government repression from the authoritarian era, pressing challenges and dilemmas for these groups now stem from depoliticized and managerial forms of democracy - a situation which seemed improbable just a decade ago.

We wish to acknowledge and thank Doi Ra, April Kyu Kyu, and Soe Soe Htway who provided invaluable advice and assistance in fieldwork. We are also grateful to the civil society researchers and academics as well as local residents in Myanmar who took time to speak with us and who shaped this analysis. The research presented here was supported by funding provided by a Melbourne 
Sustainable Society Institute seed grant (2018-2019).

Main image: A village in the New Yangon City development site. Credit: Vanessa Lamb 